\title{
Australian Journal of

\section{Yield index of crops grown under no-tillage after superficial application of micronized liming materials (MLM) on the soil}

\author{
Jessica Alves Nogaroli , Adriel Ferreira da Fonseca \\ State University of Ponta Grossa, Carlos Cavalcanti avenue, Ponta Grossa, Paraná, Brazil \\ *Corresponding author: jessica_jas@icloud.com
}

\begin{abstract}
The development of strategies for the control of soil acidity in production systems using micronized liming material (MLM) could be a strategy in areas under no-till (NT) to produce high crops yield. The micronized liming material (MLM) have faster reaction on the soil surface even without incorporation to the soil. The experimental design used was completely randomized blocks in split-plot with four replications in a Typic Distrudept under NT treated with MLM. In the main plots the dolomitic limestone (DL) and MLM (granulated micronized calcite (GMC); granulated micronized dolomite (GMD) and carbonated suspension (CS) were studied. In the subplots, four doses of liming materials aiming were assigned to increase soil base saturation (BS) to 50,70 and $90 \%$, besides of control treatment. We measured the relative yield (RY), relative yield change (RYC) and production efficiency (PE) of wheat, soybean, black oat and maize during four consecutive years (2012 to 2016). The MLM presented major RY and PE along experimental period than DL. Besides, the major RYC of MLM refers to lower responsiveness, major residual effect as well as major or maintenance crops yield. Better results were found in the BS dose aiming to $61 \%$ for all the liming materials studied for PE, showing that it is the adequate BS for control of acidity in Typic Distrudept.
\end{abstract}

Keywords: Production efficiency; relative yield change; relative yield; soil reaction; Typic Distrudept.

\section{Introduction}

The soil acidity control is essential for increasing yields and plant growth of the wheat, soybean and maize (Bolan et al., 2008; Valentinuzzi et al., 2015, Caires et al., 2015), especially in tropical and subtropical regions. In these regions, there is the dominance of variable charge soil, which present peculiar physic-chemical attributes, as cation exchangeable capacity dependens to the soil organic matter (Holland et al., 2018). Thus, practice of conservational agriculture such as no-tillage (NT) is essential.

For soil, acid control has been used. It promotes increase of soil $\mathrm{pH}$, base saturation and effective cation exchange capacity values (Havlin et al., 2014; Frank et al., 2019). However, in NT the liming material (as dolomitic or calcite limestone) has been applied as surface application, without incorporation. In this case, the reaction of the liming is lower and gradual (Caires et al., 2005). In this context, it is necessary to control soil acidity with liming material of major responsiveness, as the micronized liming materials (MLM) avoided crops yield loss. Most of the study presented the results of the crops with liming materials in Oxisol. However, there is lack of studies on Typic Distrudept issue, even though it is one of the main soils of Brazil mainly in Campos Gerais Region. This region has around 389 thousand ha of Oxisol and 436 thousand of Typic Distrudept (Sá, 2007).

The MLM is characterized and found as granulated micronized calcite (GMC) or dolomite (GMD) and carbonated suspension (CS), due to the fineness and particles pelletized or in suspension with water; efficient to increase soil $\mathrm{pH}$ and decrease $\mathrm{H}+\mathrm{Al}$ and $\mathrm{Al}$ concentrations and source of exchangeable-Ca and $\mathrm{Mg}$ in short-term (Dos Santos et al., 2016a and b). It presented easier handling, uniform application, generally react faster in soil and reduced dust than common liming material. However, its use in agriculture is increasing (Havlin et al., 2014).

The yield of crops is the result of various interactions between environments, climate, soil attributes, agronomic management, genetic material, rainfall, solar radiation, photoperiod etc. (Van Ittersum and Rabbinge, 1997; Andrea et al., 2018). However, for greater knowledge, the crop yield rates are important for agriculture, mainly when technology for world or national food security is employed (Fischer et al., 2014; Liu et al., 2016). The crop yield rates can be relative yield (RY), relative yield change (RYC) and production efficiency (PE). The RY takes the crops yield data into the account after each treatment (i.e. after application of liming material). The RYC also takes into the account the relative yield change between the years of crops growth (Ewert et al., 2005). The PE applies the crop yield sum after each treatment (i.e. after application of liming material). Same factors such as soil acidity control can increase or reduce the crop yield index (Grassini et al., 2013; Merlos et al., 2015).

There are few studies regarding the MLM grains and dry matter yields index (RY, RYC, and PE) of wheat/soybean/black oat/maize cropped in succession under NT. These indexes help the measured yield evolution 
in space and temporal scale in the actual conditions of weather, soil, farmer's knowledge and technologies (FAO, 2015, Guilpart et al., 2017). In this way, we can use the yield index for soil fertility science using soil acidity as limiting factor and not only for some limiting factors such as water and weather (van Oort et al., 2017).

In this work, we measured yield index (RY, RYC and PE) of wheat, soybean, black oat and maize for four consecutive years (during the years of 2012 up to 2016) in a Tyic Distrudept under NT, treated with MLM. We hypothesized that the MLM can help the crop to avoid yield loss after surface application of Typic Distrudept under NT during 45 months. Then the required liming material can be recommended for Typic Distrudep in the region.

\section{Results}

The yield index of all studied crops considered the absolute yield (in kg ha ${ }^{-1}$ ). Therefore, for calculations of yield index we used the absolute data of crops yield (Table 1) after application of liming materials in all the dosages aiming to soil base saturation (BS) of 50, 70 and $90 \%$ more than control treatment (dosage 0 ).

\section{Results of relative yield (RY)}

For RY results, there were some interactions between liming materials and dosages, as for wheat $2012(F=7.08 ; p<$ 0.0001 ), soybean 2012/13 ( $F=3.58 ; p<0.0034)$, black oat $2013(F=6.53 ; p<0.0001)$ and $2015(F=3.97 ; p<0.0018)$. For wheat 2012, higher RY was observed in MLM than DL (Fig 1a). Major RY of wheat (2014) were observed in DL than MLM, and in the dosages of BS between 50 and $70 \%$ (Fig 1b). For wheat (2014), after obtaining the equation derivative, the higher GRY was in the dosage $5.95 \mathrm{Mg} \mathrm{ha}^{-1}$ of $\mathrm{DL}$ or the dosage that increase BS to $68 \%$ (Fig 1b). The RY of maize $(2013 / 14)$ was major in CS followed by DL, GMD and GMC (Fig 1C). For maize (2015/16), there is no differences for liming materials applied (Fig 1d). However, for maize (2013/14), higher RY was observed in the dosages of BS between 50 and $70 \%$ (Fig 1c). For maize (2013/14), after obtaining of equation derivative, the higher GRY was observed in the dosage of $5.02 \mathrm{Mg} \mathrm{ha}^{-1}$ of CS or the dosage increasing BS to 55 \% (Fig 1C). The RY was major for soybean (2012/13) after application of DL and CS than the others (Fig 2a). For soybean (2014/15) we observed major RY in GMC and CS than DL and GMD (Fig 2b). For black oat (2013) we observed major RY in GMD than others liming materials (Fig 2c). Major RY of black oat 2015 were observed in DL than the MLM (Fig 2d).

\section{Relative yield change (RYC) and production efficiency (PE)}

For RYC results, there was an interaction between liming materials and dosages such as those for black oat $(F=3.18 ; p$ $<0.0074)$. The DL for RYC, without liming material, was 0.3 , $1.5,1.0$ and $1.0 \%$ for wheat, soybean, black oat and maize, respectively (Fig 3 ). We considered the effect of liming materials and dosages applied in each crop in two cycles of crop succession. For the wheat, the GMD and DL presented major RYC than others liming materials but, only DL decreased RYC as the applied dosage was increased (Fig 3). For soybean, the CS performed major RYC followed by DL > GMD > GMC (Fig 3). Major RYC of black oat was observed by using GMC and GMD, which presented similar and upper results than DL and CS (Fig 3). Also, there is decrease of black oat RYC, while the dosages of DL was increased (Fig 3 ). There were no differences between the liming materials in maize (Fig 3).

For $\mathrm{PE}$ results, there was an interaction between liming materials and dosages on grains $(F=7.64 ; p<0.0001)$. The $\mathrm{DL}$ of control treatment for PE was 4500 and $1500 \mathrm{~kg}$ of grains and dry matter, respectively, by amount $(\mathrm{Mg})$ of liming materials applied on the soil (Fig 4). The control treatment without liming material was of $0.0 \mathrm{~kg}$ PE of grains and dry matter by amount $(\mathrm{Mg})$ of liming materials applied to the soil (Fig 4). For grains, higher PE was observed for GMC and GMD up to 45 months (Fig 4). For dry matter PE, there was no differences between the liming materials (Fig 4). However, for grains and dry matter, higher PE was observed for the dosage of liming material targeting BS to a range of $50 \%$ (Fig 4). For grains, after obtaining of equation derivative, the higher PE was observed in the dosages of $4.93,4.88,4.69$ and $6.22 \mathrm{Mg} \mathrm{ha}^{-1}$ of DL, GMC, GMD and CS, respectively (Fig 4). Theses dosages aimed at BS of $61 \%$. For dry matter, after obtaining of equation derivative, the higher PE was observed by applying dosages of $4.91,4.86,4.68$ and $6.03 \mathrm{Mg} \mathrm{ha}^{-1}$ of DL, GMC, GMD and CS, respectively (Fig 4). Theses dosages aimed BS of $61 \%$.

\section{Discussion}

\section{Understanding the control of soil acidity and relative yield}

Considering the RY, we observed that the MLM react much faster but present little residual effect than $\mathrm{DL}$, in short-term (5-10 months after application), mainly in wheat (2012) and soybean (2012/13) (Fig 4 and 5). However, the DL in all dosages studied of the experimental soil (Typic Distrudept), showed effect on maize (2013/14) (after 24 months of surface application) (Fig 2). As there is limited number of studies on Typic Distrudept, we will discuss it with other soils. At NT condition, no similar effect was observed in Oxisol by using DL treatment (surface application and ECC = $850 \mathrm{~g} \mathrm{~kg}^{-1}$ ) in a dosage that takes up BS to $70 \%$. It lasted about 72 months for acidity control (Caires et al., 2015). Generally, the GMC and CS presented better RY than DL and GMD due to significant concentration of calcium than magnesium and this conferred greater solubility (Grunwaldt et al., 2016; Vargas et al., 2019). The application of MLM resulted in Typic Distrudept acidity control (Dos Santos et al., 2016b). However, the soil acidity control favored the crop growth (Bolan et al., 2008; Caires et al., 2015) and increased RY (Liu et al., 2004; Barbieri et al., 2015).

However, in this experiment we observed high yields, even in control treatment, when compared with Brazilian mean (Table 1). The Brazilian mean yield (estimated) of years 2017/18 for wheat, soybean, black oat and maize was 2431, 3276, 2210 and $5556 \mathrm{~kg} \mathrm{ha}^{-1}$, respectively (Conab, 2018). The rainfall and temperature of Palmeira City (Fig 6), as well as the crops rotation (Fig 7) could influence the results of this work. 


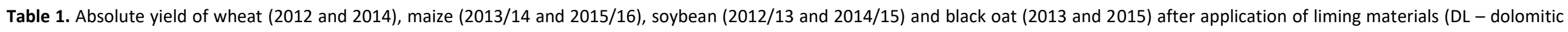

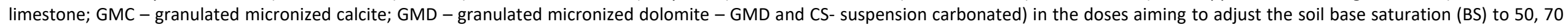
and $90 \%$, besides control treatment (dose 0 ).

\begin{tabular}{|c|c|c|c|c|c|c|c|c|}
\hline & Wheat 2012 & Wheat 2014 & Maize $2013 / 14$ & Maize 2015/16 & Soybean $2012 / 13$ & Soybean $2014 / 15$ & Black oat 2013 & Black oat 2015 \\
\hline & $\mathrm{Kg} \mathrm{ha}^{-1}$ & & & & & & & \\
\hline \multicolumn{9}{|l|}{$\mathrm{DL}$} \\
\hline 0 & $2482^{*}$ & 1225 & 9696 & 12061 & 2727 & 3945 & 5015 & 6145 \\
\hline 50 & 2477 & 694 & 10539 & 13180 & 2867 & 4831 & 6691 & 4791 \\
\hline 70 & 3263 & 963 & 10620 & 11634 & 2766 & 3619 & 6586 & 5611 \\
\hline 90 & 2891 & 671 & 10660 & 11812 & 2580 & 3916 & 5737 & 4278 \\
\hline \multicolumn{9}{|c|}{ GMC } \\
\hline 0 & 3668 & 700 & 10447 & 11479 & 2713 & 4023 & 2741 & 2994 \\
\hline 50 & 3350 & 658 & 13291 & 13138 & 2681 & 3812 & 6327 & 5102 \\
\hline 70 & 2612 & 767 & 11136 & 11904 & 2689 & 3829 & 5951 & 5872 \\
\hline 90 & 3309 & 563 & 12070 & 12550 & 3238 & 4648 & 5633 & 4672 \\
\hline \multicolumn{9}{|c|}{ GMD } \\
\hline 0 & 3452 & 863 & 10824 & 12483 & 2392 & 3829 & 5758 & 4013 \\
\hline 50 & 2515 & 1200 & 11113 & 13683 & 2755 & 4333 & 6034 & 4734 \\
\hline 70 & 3136 & 1481 & 10262 & 12570 & 2663 & 4017 & 4639 & 4526 \\
\hline 90 & 2913 & 1279 & 11188 & 13355 & 2676 & 3730 & 4797 & 5431 \\
\hline \multicolumn{9}{|l|}{ CS } \\
\hline 0 & 3458 & 940 & 11398 & 12284 & 2449 & 4523 & 5329 & 4312 \\
\hline 50 & 3562 & 758 & 10004 & 12318 & 2398 & 4702 & 8535 & 5023 \\
\hline 70 & 2427 & 604 & 10330 & 14526 & 2578 & 3360 & 6438 & 4942 \\
\hline 90 & 2901 & 642 & 12973 & 14104 & 2283 & 3878 & 7393 & 4715 \\
\hline
\end{tabular}

Table 2. Dosages of the liming materials applied on the soil surface, without incorporation, aiming to adjust the soil base saturation (BS) to 50,70 and $90 \%$.

\begin{tabular}{|c|c|c|c|c|}
\hline \multirow{2}{*}{ Aimed BS (\%) } & \multicolumn{4}{|c|}{ Liming materials $\left(\mathrm{Mg} \mathrm{ha}^{-1}\right)$} \\
\hline & $\mathrm{DL}^{2}$ & $\mathrm{GMC}^{3}$ & $\mathrm{GMD}^{4}$ & $\mathrm{CS}^{5}$ \\
\hline $50^{1}$ & 3.22 & 3.18 & 3.05 & 3.98 \\
\hline $70^{1}$ & 6.28 & 6.21 & 5.94 & 7.76 \\
\hline $90^{1}$ & 9.34 & 9.23 & 8.83 & 11.54 \\
\hline
\end{tabular}

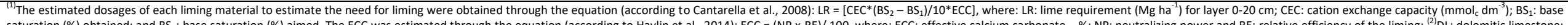

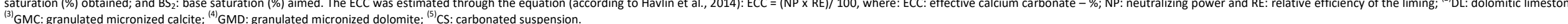
reapplications. 

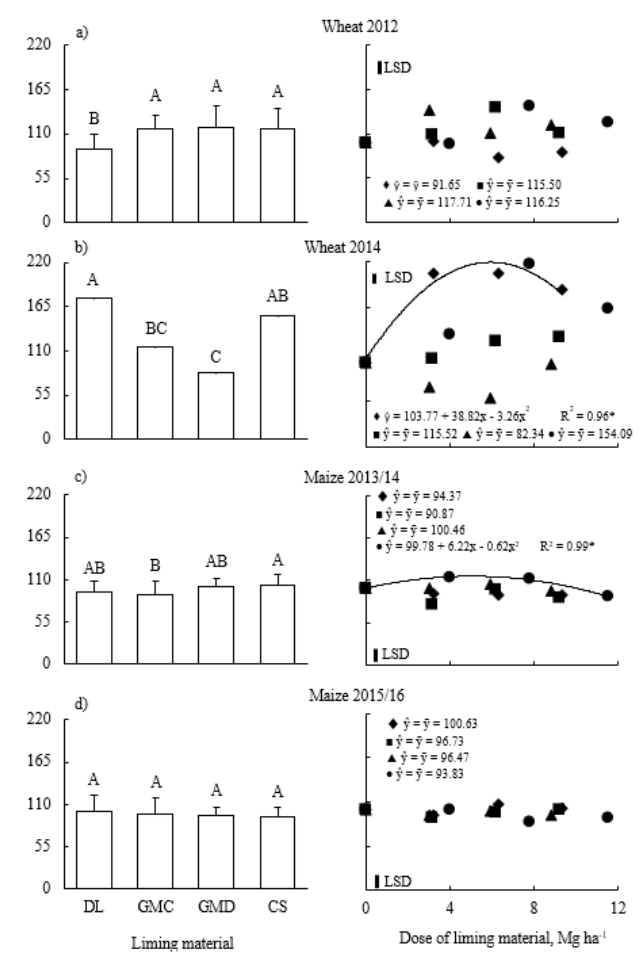

Fig 1. Grains (GRY) relative yield (\%) ( $n=16 \pm$ standard deviation) of wheat ( $a$ and $b$ ) and maize (c and d) cropped under no-tillage, after surface application of the liming material dosages (in June/2012). ( $\downarrow$ ) Dolomitic limestone - DL. (घ) Granulated micronized calcite - GMC. ( $\boldsymbol{\Delta})$ Granulated micronized dolomite - GMD. (•) Carbonated suspension - CS. Averages followed by the same letter do not differ statistically (Tukey test, $\alpha=0.05$ ). Vertical bars indicate the least significant difference (LSD). ${ }^{*}: \mathrm{P}<0.05{ }^{* *}: \mathrm{P}<0.01$.

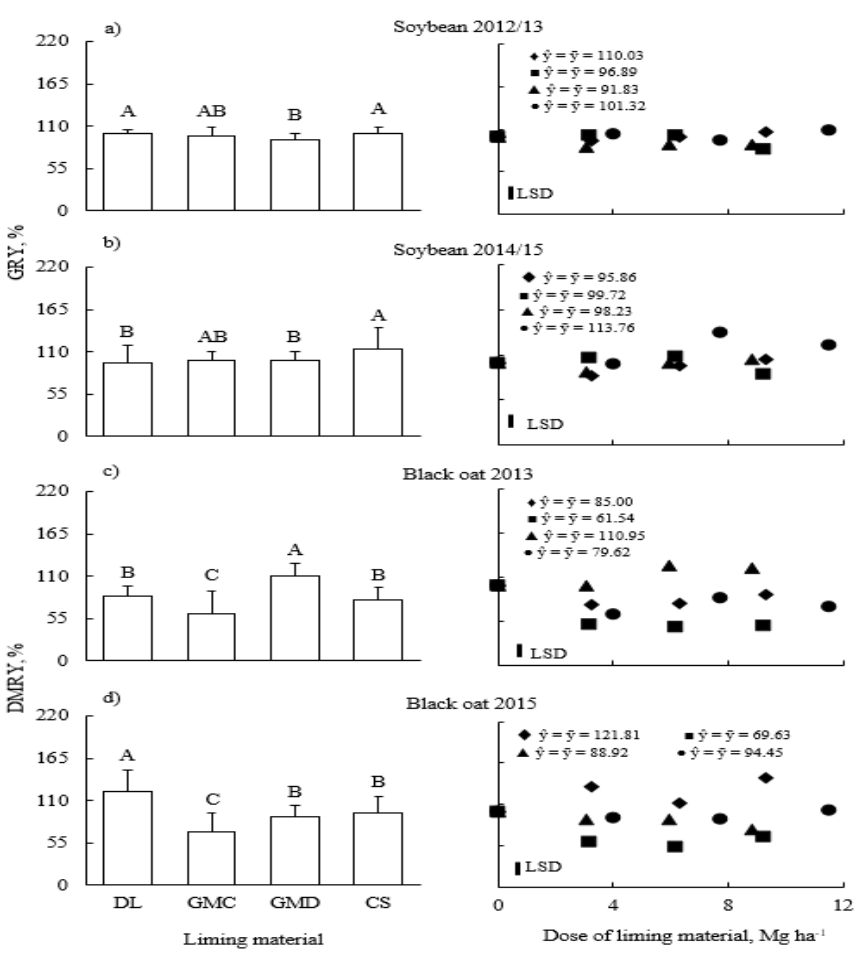

Fig 2. Grains (GRY) and dry matter relative yield (DMRY) (\%) ( $n=16 \pm$ standard deviation) of soybean (a and b) and black oat (c and d) cropped under no-tillage after surface application of the liming material dosages (in jun/2012). ( $\bullet$ ) Dolomitic limestone - DL. ( $\square$ ) Granulated micronized calcite - GMC. ( $\Delta$ ) Granulated micronized dolomite - GMD. (•) Carbonated suspension - CS. Averages followed by the same letter do not differ statistically (Tukey test, $\alpha=0.05$ ). Vertical bars indicate the least significant difference (LSD). *: $\mathrm{P}<0.05{ }^{* *}: \mathrm{P}<0.01$. 

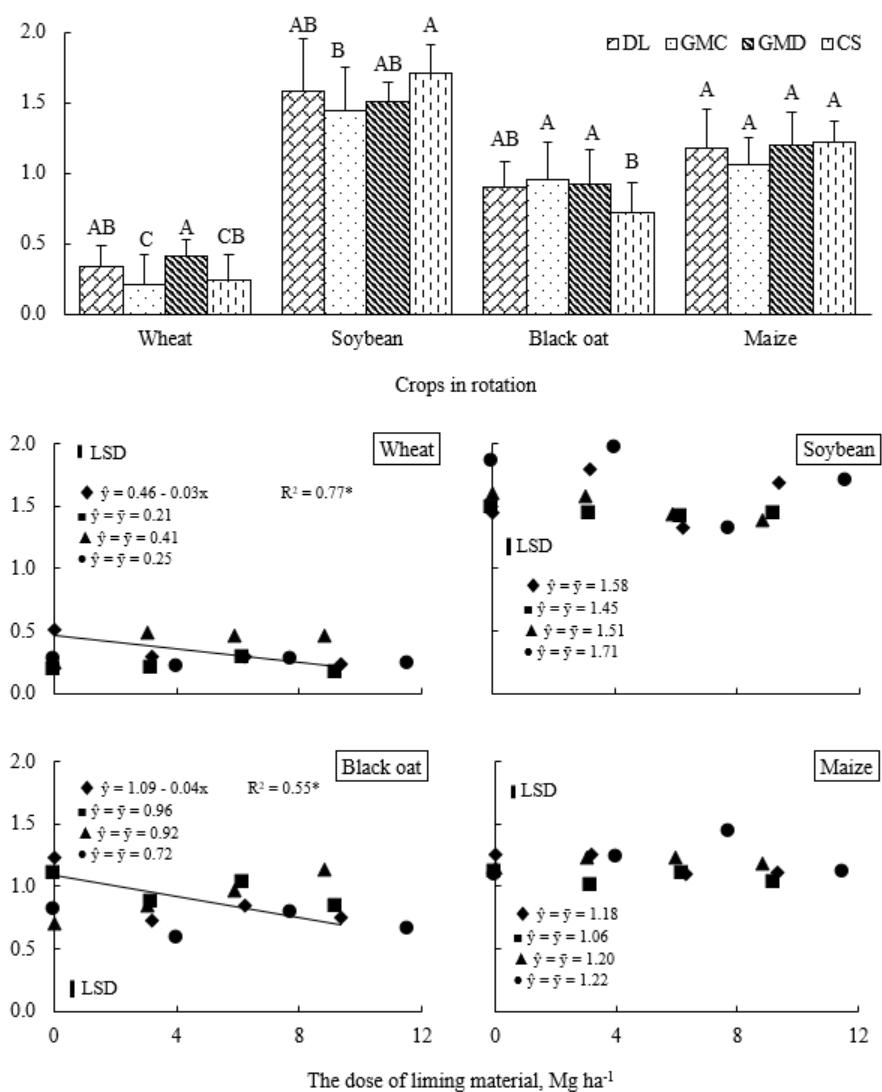

Fig 3. Relative yield change (\%) ( $n=16 \pm$ standard deviation) of grains of wheat, soybean and maize; and dry matter of black oat in two cycles of crops succession under no-tillage up to 45 months after surface application of dosages of liming material (in

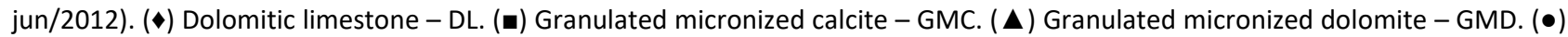
Carbonated suspension - CS. Means followed by the same letter do not differ statistically by Tukey test $(\alpha=0.05)$. Vertical bars indicate the least significant difference (LSD). *: $\mathrm{P}<0.05$. $^{*}$ : $\mathrm{P}<0.01$.
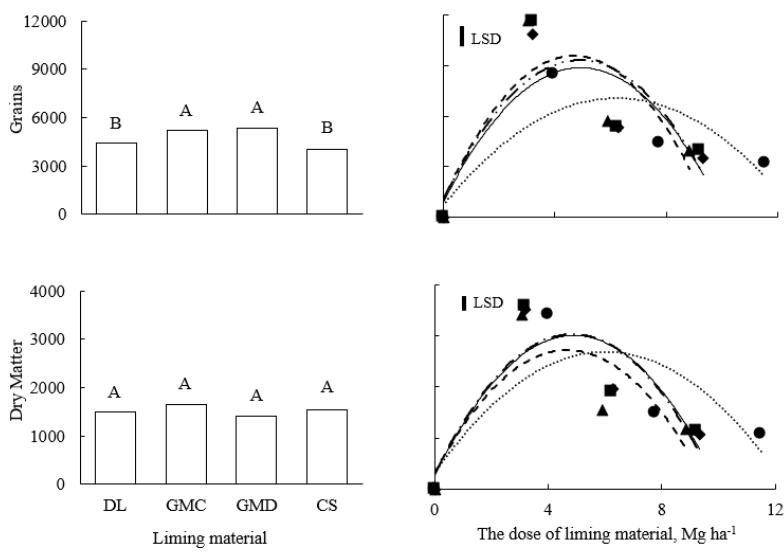

Equations grains:

$\hat{\mathrm{y}}=923.1+3219.8 \mathrm{x}-326.7 \mathrm{x}^{2} \quad \mathrm{R}^{2}=0.69 * *$ - $\hat{y}=1059.6+3374.7 x-345.2 x^{2} R^{2}=0.64 * *$

$\hat{\mathrm{y}}=1004.7+3650.1 \mathrm{x}-389.2 \mathrm{x}^{2} \mathrm{R}^{2}=0.68 * *$

- $\hat{y}=716.9+2037.8 x-163.9 x^{2} \quad R^{2}=0.69 * *$

Equations dry matter

औ $\hat{\mathrm{y}}=265.1+1114.5 \mathrm{x}-113.4 \mathrm{x}^{2} \quad \mathrm{R}^{2}=0.76^{* *}$

- $\hat{y}=285.1+1130.1 \mathrm{x}-116.3 \mathrm{x}^{2} \quad \mathrm{R}^{2}=0.74 *$

$\Delta \hat{\mathrm{y}}=310.7+1030.3 \mathrm{x}-110.1 \mathrm{x}^{2} \quad \mathrm{R}^{2}=0.64 *$

$\bullet \hat{y}=317.8+785.1 x-65.1 x^{2} \quad R^{2}=0.63^{*}$

Fig 4. Production efficiency (kg grains or dry matter by $\mathrm{Mg}$ of liming material applied on the soil, without incorporation) ( $n=16 \pm$ standard deviation) of grains of wheat, soybean and maize; and of dry matter of black oat growth under no-tillage up to 45 months after surface application of doses of liming material (in jun/2012). ( and solid line) Dolomitic limestone - DL. ( $\bullet$ and segmented line) Granulated micronized calcite - GMC. ( $\boldsymbol{\Delta}$ and dashed line) Granulated micronized dolomite - GMD. ( $\bullet$ and asterisks line) Carbonated suspension - CS. Averages followed by the same letter do not differ statistically (Tukey test, $\alpha=0.05$ ). Coefficient of variation was of 9.86 and $18.24 \%$ for grains and dry matter, respectively. Vertical bars indicate the least significant difference (LSD). $*$ : $\mathrm{P}<0.05{ }^{* *}: \mathrm{P}<0.01$. 


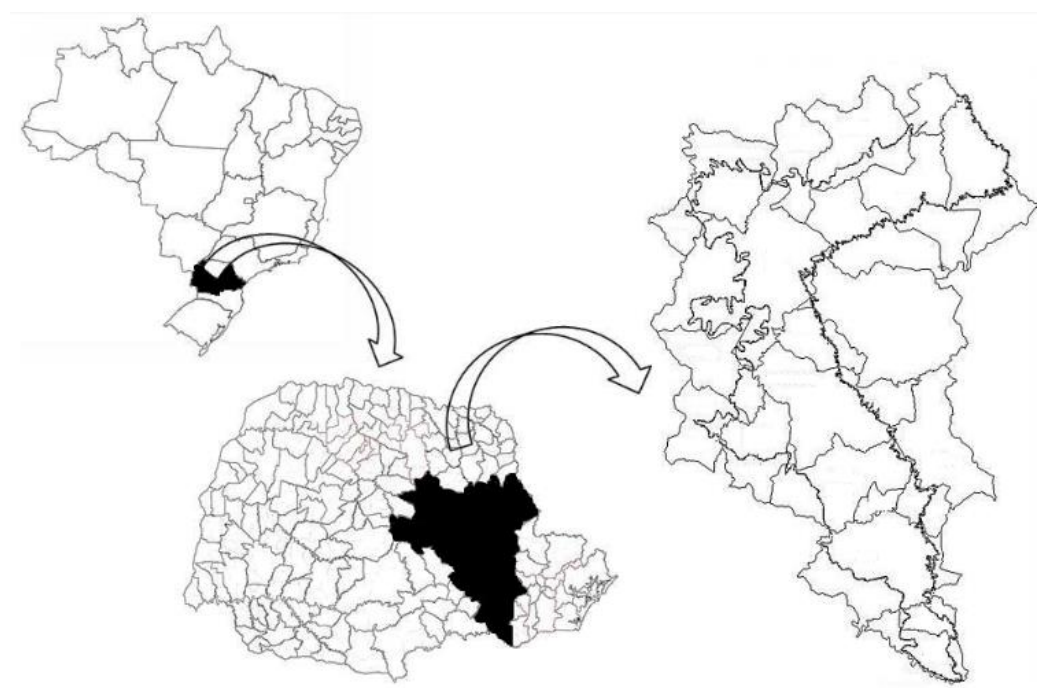

Fig 5. Map of the Campos Gerais Region - Paraná - Brazil (around 1.17 million ha). The soils predominant are Typic Distrudept (around 436 thousand ha) and Oxisol (around 389 thousand ha), being in the Palmeira municipality $\left({ }^{*}\right)$ the Typic Distrudept is more representative for grains production Adapted from Sá (2007).

The rainfall and temperature influenced the liming material dissolution in the soil and the growth of crops. The crop rotation indicate a greater input of fertilizers and phytomass accumulation (Van Ittersum and Rabbinge, 1997; Caires et al., 2005; Bolan et al., 2008; Andrea et al., 2018). The crop rotation in NT is important for maintenance of crop yield (Jokela and Nair, 2016). For example, considering only wheat on agricultural planning, the loss can be around $500 \mathrm{~kg} \mathrm{ha}^{-1}$ (Mazzilli et al., 2016). Therefore, crop rotation can keep the crop yield up and reduce yield risks (Ernst et al., 2016).

Besides, the soil of experimental area represented (Typic Distrudept) lower $\mathrm{pH}(4.3)$, aluminum saturation (23\%) and BS value (29\%). In the meantime, it presented medium cation exchangeable capacity (CEC) value $\left(146 \mathrm{mmol}_{\mathrm{c}} \mathrm{dm}^{-3}\right)$ and higher organic carbon $\left(21 \mathrm{~g} \mathrm{dm}^{-3}\right.$ ) (interpretation according to SBCS, 2017). This fact can justify the higher yield crops as well as the absence of crop responses, the major dosages applied of liming material (BS aiming to 70 and $90 \%$ ) (SBCS, 2017). If we consider only wheat and maize RY, the Typic Distrudept shows diversity in its chemical attributes until the liming material aims at BS between 55-68 $\%$.

\section{Yield rates after soil acidity control}

The wheat was influenced by rain in 2014 (Fig 6) resulting in a lower yield in the second crop. A significant variability of soybean RYC may have been the difference of crop water availability between the two years of growth (Fig 6). Thus, the lower change between two years of growth of a crop can be due to superior responsiveness in short-term, major residual effect of liming material and yield maintenance in a crop rotation up to four years. However, the major change between two years of growth of a crop can be due to slow liming dissolution over the years and a significant increase of yield only in the last crop. We can suggest that the soil acidity control with MLM, mainly CMG and CS, promotes smaller change and yield maintenance between two years of growth of a crop.

However, at constant rainfall condition, the acidity control is more important than others factors around the world such as (i) crop rotation with plants species C3 and C4 under NT (Farmaha et al., 2016), (ii) integrated soil-crop system management (Liu et al., 2016) and (iii) the crop water availability that may impact RYC of wheat, soybean, and maize (Grassini et al., 2015; Merlos et al., 2015). In maize, there is no differences between the liming materials and your dosages (Grassini et al., 2013; Zhao et al., 2015) (average of maize grains on experiment $11863 \mathrm{Mg} \mathrm{ha}^{-1}$ ), where is generally found in Campos Gerais Region (Table 1). For both grain and DM, the dosage that aimed to increase BS to $50 \%$ (Table 2) presented major PE than the dosages that aimed to increase BS to 70 and $90 \%$ (Fig 4) in a Typic Distrudept. However, the BS aiming at $50 \%$, after the equation derivative, became $61 \%$ (Fig 4). This result is different with those observed in others soils such as Oxisol, for the same crops as this study (BS aiming $70 \%$ ). The lime requirement (LR) is dependent on each crop (Farhoodi and Coventry, 2008) for the Typic Distrudept (conditions of this study). Regardless of type of liming material, the recommended BS is $61 \%$.

\section{Materials and Methods}

\section{Characterization of environments}

The experiment was carried out in Palmeira, Paraná state, Brazil, region of Campos Gerais of Paraná (S2524'37.8" W49-58'22,8" ( $\pm 3 \mathrm{~m}$ ) alt. $900 \mathrm{~m}$ ) (Fig 5) in a Typic Distrudept (Inceptisol) soil. This region presents 37\% (436 thousand ha) of area with Typic Distrudept (Sá, 2007) and its characteristics by higher grains yields in Brazil.

The experimental area was cropped in no-tillage system (NT) in the past 15 years, cropping black oat in the fall, and soybean, in the summer. In the beginning of the experiment, the soil showed following attributes in the $0-20 \mathrm{~cm}$ layer (according Pavan et al., 1992): 4.3 of $\mathrm{pH}\left(\mathrm{CaCl}_{2}\right), 23 \%$ of aluminum saturation $(\mathrm{m}), 146 \mathrm{mmol}_{\mathrm{c}} \mathrm{dm}^{-3}$ of CEC, $29 \%$ of BS, $23 \mathrm{mg} \mathrm{dm}^{-3}$ of available phosphorus (Mehlich-1) and 21.0 $\mathrm{g} \mathrm{dm}^{-3}$ of organic carbon (Walkey-black).

The local weather is Cfb (humid subtropical climate), according to Köppen-Geiger classification. Monthly rainfall 
and temperature of the site, over the experimental period (May/2012 to Apr/2016) are presented in Fig 6.

\section{Design experimental and liming materials}

The experimental design was completely randomized blocks in split-plot with four replications. In the plots $\left(384 \mathrm{~m}^{2}\right)$, we studied four liming materials: dolomitic limestone (DL), granulated micronized calcite (GMC), granulated micronized dolomite (GMD) and carbonated suspension (CS). In the subplots $\left(96 \mathrm{~m}^{2}\right.$ ) four doses of the liming materials were applied aiming to increase BS to 50, 70 and $90 \%$, besides of control treatment (without liming material). All dosages of the liming materials were applied in the soil surface, without incorporation, only once, in Jun/2012. After this, no liming material was applied in the experimental area.

The dosages estimated to increase BS (to 50, 70 and $90 \%$ ) which was obtained through the equation according Cantarella et al. (1998). It can be observed in Table 2. The effective calcium carbonate (ECC) of liming materials evolved from calcium carbonate equivalent (CCE), fineness factor (or relative efficiency - RE) of the liming and neutralizing power (Havlin et al., 2014). The MLMs were either pelletized such as the CMG and DMG, or fluid limes like CS, presenting fine particle size, keeping neutralizing value low (Havlin et al., 2014). The RE value was $100 \%$, according to Dos Santos et al. (2016b). The calcium (Ca), magnesium (Mg) and ECC values of liming materials were 216.6, 135.1 and $952.0 \mathrm{~g} \mathrm{~kg}^{-1}$ for DL; 330.4, 9.3 and $962.7 \mathrm{~g}$ $\mathrm{kg}^{-1}$ for GMC; $247.2,73.28$ and $1006.5 \mathrm{~g} \mathrm{~kg}^{-1}$ for GMD; 258.1, 5.0 and $770.0 \mathrm{~g} \mathrm{~kg}^{-1}$ for CS, respectively. More information about the physical and chemical attributes of liming materials are presented in Dos Santos et al. (2016a and b), except for DL. The DL in this work presented $952 \mathrm{~g} \mathrm{~kg}^{-1} ; 1099$ $\mathrm{g} \mathrm{kg}^{-1}$ and $303 \mathrm{~m}^{2} \mathrm{~kg}^{-1}$ of the ECC, CCE and specific surface area, respectively.

\section{Crops growth and sampling}

After application of the treatments, wheat, soybean, black oat and maize were cropped for 45 months (Fig 7). These crops are the most representative as well as in Campos Gerais Region (Paraná State) and Southern Brazil. The input of mineral fertilizers for these crops was shown in Table 3. All the common crop protection strategies in the region were used.

When the grain crops were in the physiologic maturity stage, the harvest was performed sampling $6.0 \mathrm{~m}^{2}$ per subplots (taking into account only middle rows). The wheat, soybean and maize grains were threshed (BC-80 III model), weighed, and their yields expressed by $130 \mathrm{~g}$ water $\mathrm{kg}^{-1}$. Regarding the dry matter, samples of the black oat were collected from randomized $1.0 \mathrm{~m}^{2}$ per subplots. The samples were ovendried at $65^{\circ} \mathrm{C}$ until they reached constant dry matter, weigh and measured dry matter yield.

\section{Analyses of yield index}

The RY, RYC and PE of wheat, soybean, black oat and maize were estimated after 5, 10, 15, 22, 28, 33, 37 and 45 months after surface application of liming materials in the soil. The RY was calculated by equation 1, according to Raij (2011):

$$
R Y=\frac{T 0}{T n} \times 100
$$

Where; RY is: Relative yield or sufficiency percentage (\%); $\mathrm{T}_{0}$ : grains or dry matter yield in the control treatment (without application of liming material) ( $\left.\mathrm{kg} \mathrm{ha}^{-1}\right) ; \mathrm{T}_{\mathrm{n}}$ : grains or dry matter yield after application of liming material dosages ( $\mathrm{kg}$ $\mathrm{ha}^{-1}$ ).

The RYC was estimated by equation 2, adapted from Ewert et al. (2005):

$R Y C=\frac{Y e(t y)}{Y e(t y-1)}$

Where; RYC is: relative yield change; $\mathrm{Y}_{\mathrm{e}}$ : yield of grains or dry matter $\left(\mathrm{kg} \mathrm{ha}^{-1}\right)$; $\mathrm{t}_{\mathrm{y}}$ : year of crop growth; $\mathrm{t}_{\mathrm{y}}-1$ : previous growth year of the same crop.

The PE was measured by equation 3:

$P E=\frac{Y s}{D}$

Where; PE is: production efficiency (kg of grains or dry matter / $\mathrm{Mg}$ of liming material); $\mathrm{Y}_{\mathrm{s}}$ : yield sum of grains or dry matter up to 45 months after soil surface application of liming materials $\left(\mathrm{kg} \mathrm{ha}^{-1}\right)$; $\mathrm{D}$ : dosage of liming material applied on soil in jun/2012 (Mg ha ${ }^{-1}$ ) (Table 2).

\section{Statistical analyses}

Data were submitted for statistical analysis employing the computer program SAS Version 9.1.2 (SAS, 2004). The effects of liming materials (DL, GMC, GMD and SC) and dosages applied (to increase BS to 50,70 and $90 \%$ besides to the control treatment) on crops yield were assessed using: (i) the analysis of variance employing the PROC GLM and Tukey's test ( $\alpha=0.05$ ); and (ii) the analysis of regression employing the PROC REG and least significant difference (LSD). Just the wheat RY date was transformed to $\log _{10}$. The equation of quadratic regression derived from the equation of the second degree. The control treatment for liming material is the DL and for dosages is without application of liming materials.

\section{Conclusions}

The micronized liming materials (calcite > carbonated suspension > dolomite) presented major relative yield, relative yield change and production efficiency of wheat, soybean, black oat and maize up to 45 months that the dolomitic limestone. This fact confirmed one of our hypotheses that liming materials reduce the yield loss after surface application in Typic Distrudept under no-tillage.

The dosages of micronized liming materials that aimed to increase the soil base saturation to 55 and $68 \%$ resulted in major relative yield. A lower relative yield between two years of cropping, major responsiveness and residual effect of micronized liming material (mainly calcite micronized granulated and carbonated suspension), and yield in a crop succession of four years were observed. The production efficiency of grains was major after application of calcite and dolomite micronized granules. If we consider only production efficiency of grains and dry matter, better results were found in the dosage aiming the soil base saturation to $61 \%$ for all the liming materials, showing that it is the 
recommended dosage for acidity control of a Typic Distrudept.

\section{Acknowledgments}

These authors would like to show gratitude for the support of CNPq, CAPES, Omya do Brasil, and for the use of the research facilities of the Multi-User Laboratories Complex (CLABMU/PROPESP/UEPG) and students of reaserch group.

\section{References}

Andrea MCS, Booteb KJ, Sentelhas PC, Romanelli TL (2018) Variability and limitations of maize production in Brazil: Potential yield, water-limited yield, and yield gaps. Agric Sys. 165: 264-273.

Barbieri PA, Echeverria HE, Sainz Rozas HR, Martínez JP (2015) Soybean and wheat response to lime in no-till Argentinean mollisols. Soil Till Res. 152:29-38.

Bolan NS, Rowarth J, de la Luz Mora M, Adriano D, Curtin D (2008) Biological transformation and bioavailability of nutrient elements in acid soils as affected by liming. In Naidu, R. (ed.), Chemical Bioavailability in Terrestrial Environments. Elsevier B.V.

Caires EF, Alleoni LRF, Cambri MA, Barth G (2005) Surface application of lime for crop grain production under a no-till system. Agron J. 97:791-798.

Caires EF, Haliski A, Bini AR, Scharr DA (2015) Surface liming and nitrogen fertilization for crop grain production under no-till management in Brazil. Eur J Agron. 66:41-53.

Cantarella H, Van Raij B, Quaggio JA (1998) Soil and plant analyses for lime and fertilizer recommendations in Brazil. Commu Soil Sci Plant Anl. 29:1691-1706.

Conab (2018) Acompanhamento safra brasileira de grãos Safra 2017/18, sétimo levantamento, 7, Brasília, Brasil.

Dos Santos JA, Da Fonseca AF, Zocco D, Vieira I (2016a) Exchangeable cations and available phosphorus in soils with variable charge after application of special liming materials. Afr J Agric Res. 11: 2744-2760.

Dos Santos JA, Da Fonseca AF, Zocco D, Vieira I (2016b) Special liming materials for acidity control of soils with variable charge. Afr J Agric Res. 11: 2920-2936.

Ernst OR, Kemanian AR, Mazzilli SR, Cadenazzi M, Dogliotti S (2016) Depressed attainable wheat yields under continuous annual no-till agriculture suggest declining soil productivity. Field Crop Res. 186:107-116.

Ewert F, Rounsevell MDA, Reginster I, Metzger MJ, Leemans R (2005) Future scenarios of European agricultural land use I. Estimating changes in crop productivity. Agr Ecosyst Environ. 107:101-116.

FAO, DWFI (2015) Yield gap analysis of field crops - Methods and case studies. In: Sadras VO, Cassman KGG, Grassini P, Hall AJ, Bastiaanssen WGM, Laborte AG, Milne AE, Sileshi G, Steduto P (eds) FAO Water Reports, 41, Rome, Italy.

Farhoodi A, Coventry DR (2008) Field crop responses to lime in the mid-north region of South Australia. Field Crop Res. 108:45-53.

Farmaha BS, Lobell DB, Boone KE, Cassman KG, Yang HS, Grassini P (2016) Contribution of persistent factors to yield gaps in high-yield irrigated maize. Field Crop Res. 186:124132.

Fischer RA, Byerlee D, Edmeades GO (2014) Crop yields and global food security-will yield increase continue to feed the world? ACIAR Monograph, 158, Australian Centre for International Agricultural Research, Canberra.

Frank T, Zimmermann I, Horn R (2019) The need for lime in dependence on clay content in arable crop production in Germany. Soil Til Res. 191: 11-17.

Grassini P, Eskridge KM, Cassman KG (2013) Distinguishing between yield advances and yield plateaus in historical crop production trends. Nature 4:1-11.

Grassini P, Torrion JA, Yang HS, Rees J, Andersen D, Cassman KG, Specht JE (2015) Soybean yield gaps and water productivity in the western U.S. Corn Belt. Field Crop Res. 179:150-163.

Grunwaldt HS, Zimina A, Göttlicher J, Steininger R, Grunwaldt JD (2016) Study of the relation between $\mathrm{Mg}$ content and dissolution kinetics of natural lime stone using $\mu X R F, \mu X R D$ and $\mu X A S$. J Phys Conf Ser. 712.

Guilpart N, Grassini P, Sadras VO, Timsina J, Cassman KG (2017) Estimating yield gaps at the croppins system level. Field Crop Res. 206:21-32.

Havlin JL, Tisdale SL, Nelson WL, Beaton JD (ed) (2014) Soil Fertility and Nutrient Management: An Introduction to Nutrient Management, 8th ed. Pearson, Upper Saddle River, New Jersey.

Holland JE, Bennett AE, Newton AC, White PJ, McKenzie BM, George TS, Pakeman RJ, Bailey JS, Fornara DA, Hayes RC (2018) Liming impacts on soils, crops and biodiversity in the UK: a review. Sci Total Environ. 610-611:316-332.

Jokela D, Nair A (2016) Effects of reduced tillage and fertilizer application method on plant growth, yield, and soil health in organic bell pepper production. Soil Till Res. 163:243-254.

Liu B, Wu L, Chen X, Meng Q (2016) Quantifying the potential yield and yield gap of Chinese wheat production. Agron J. 108:1-7.

Liu DL, Helyar KR, Conyers MK, Fisher R, Poile GJ (2004) Response of wheat, triticale, and barley to lime application in semi-arid soils. Field Crop Res. 90:287-301.

Mazzilli SR, Ernst OR, Mello VP, Pérez CA (2016) Yield losses on wheat crops associated to the previous winter crop: Impact of agronomic practices based on on-farm analysis. Eur J Agron. 75:99-104.

Merlos FA, Monzon JP, Mercau JL, Taboada M, Andrade FH, Hall AJ, Jobbagy E, Cassman KG, Grassini P (2015) Potential for crop production increase in Argentina through closure of existing yield gaps. Field Crop Res. 184:145-154.

Pavan MA, Bloch MF, Zempulski HC, Miyazawa M, Zocoler DC (ed) (1992) Manual de análise química do solo e controle de qualidade, Instituto Agronômico do Paraná, Londrina.

Raij BV (2011) Fertilidade do solo e manejo de nutrientes. Piracicaba: IPNI, 420p.

Sá MFM (2007) Os solos dos Campos Gerais. In Melo MS, Moro RS, Guimarães GB (ed) Patrimônio natural dos Campos Gerais do Paraná. Ponta Grossa: Editora UEPG, 6, 73-83.

SAS System (2004) SAS Institute Inc. SAS OnlineDoc ${ }^{\circledR}$ 9.1.2. Cary, NC: SAS Institute.

Sistema Meteorológico do Paraná - SIMEPAR (2016) Dados meteorológicos do município de Palmeira - Paraná Brasil. Curitiba, Brasil.

Sociedade Brasileira de Ciência do Solo - SBCS. Núcleo Estadual Paraná (2017) Manual de adubação e calagem para o estado do Paraná. Curitiba, Brasil. 
Valentinuzzi F, Mimmo T, Cesco S, Mamun SA, Santner J, Hoefer C, Oburger E, Robinson B, Lehto N (2015) The effect of lime on the rhizosphere processes and elemental uptake of white lupin. Environ Exp Bot. 118: 85-94.

Van Ittersum M, Rabbinge R (1997) Concepts in production ecology for analysis and quantification of agricultural input-output combinations. Field Crop Res. 52:197-208.

Van Oort PAJ, Saito K, Dieng I, Grassini P, Cassman KG, Van Ittersum MK (2017) Can yield gap analysis be used to inform R\&D prioritization? Glob Food Sec. 12:109-118.
Vargas JPR, Santos DR, Bastos MC, Schaefer G, Parisi PB (2019) Application forms and types of soil acidity corrective: Changes in-depth chemical attributes in longterm period experiment. Soil Till Res. 185: 47-60.

Zhao Y, Chen X, Cui Z, Lobell DB (2015) Using satellite remote sensing to understand maize yield gaps in the North China Plain. Field Crop Res. 183:31-42. 